\title{
從佛教倫理學看待器官移植問題： 淨土宗的觀點
}

\author{
張 斌
}

摘要

器官移植的問題是當代生命倫理學的一個重要問題。如果 從人類自身利益出發, 這種被視為拯救危重病人生命的技術, 的 確是醫學科學的進步, 但它涉及的社會倫理道德問題十分廣泛。 如果從佛教倫理學——淨土宗的觀點出發, 即以緣起論來認識屍 體器官移植, 則認為器官移植會使死者因強烈的痛苦而生嗔㨫, 障礙死者往生淨土; 佛教的生死分際的判定標準——阿陀那識 執受根身則認為腦死亡概念是由於器官移植術而產生的“腦死”名 詞。另外, 佛教的護生觀和平等觀反對異種移植和器官商業化。 站在佛法的角度, 器官移植不僅有違“眾生平等”的精神, 而且可 能成為“殺生利器”。

【關鍵詞】器官移植 佛教 淨土宗

張 斌, 大連醫科大學醫學與哲學雜誌社副教授, 中國大連, 郵編：116044。

《中外醫學哲學》VI : 1 (2008 年) : 頁 77-95。

(c) Copyright 2008 by Global Scholarly Publications. 


\section{一、佛教的緣起論反對屍體器官移植}

對於單一生命器官如心臟, 屍體是唯一的供體來源。從世界範 圍來看, 屍體器官是構成器官移植的主要來源。屍體器官移植包括 無心跳的屍體供者和有心跳的腦死亡供者兩種。

從佛教的緣起論和生死分際的判定標準來分析器官移植。

\section{1. 佛教倫理的基本精神——緣起反對摘除器官}

佛教不同於世間其他宗教的核心之處就是“緣起 "。緣起的定義 簡單地説就是萬事萬物由因緣而生起的, 宇宙間的一切事物和現象 的生滅變化, 都得靠相對的互存關係或條件。在《雜阿含經》中給緣 起的定義是: “此有故彼有, 此生故彼生, 此無故彼無, 此滅故彼 滅。” 也就是説, 宇宙間的萬事萬物, 一切的一切不能脱離因緣和 合的法則。“因”是構成一切法的主要原因, “緣”是此外的次要原因。 凡是事物的生成與毀滅, 都是有因有緣的。在《雜阿含經》中對“緣 起”的解釋是：“有因有緣集世間, 有因有緣世間集; 在因有緣滅世 間, 有因有緣世間滅。”2 這裏, “世間集”説明了現象的狀態, “集世 間”剖析了現象的原因。如果單説“集”則只是説明了世間的本質, 但 這裏還説明了由“世間”而導向“出世間”的“世間滅”與“滅世間”的終 極目標與途徑方法 ${ }^{3}$ 。

佛教所説的 “緣起”不但是指萬事萬物生起的真相, 同時也指一 切萬事萬物還滅的真相。萬事萬物處在因果聯繫的網路中，依特定

（1）《雜阿含經》卷十, 大正藏第二冊, 頁 67 , 載釋昭慧: 《佛教規範倫理學》( 台北: 法界出版社, 2003 年), 頁 40-41。

(2) 《雜阿含經》卷二, 大正藏第二冊, 頁 12 , 載釋昭慧: 《佛教規範倫理學》( 台北: 法界出版社, 2003 年), 頁 40-41。

(3) 理 方: 〈佛教與現代社會——以緣起論為中心〉, 取自《首屆世界佛教論壇論文 專輯》, http://www.wuys.com。 
的條件而產生，因相互的作用而變化。通過對“緣起”的分析，我們 可知一切事物是處在“此有故彼有”, “此生故彼生”, 同時亦是“此無 故彼無”, “此滅故彼滅”的相互牽連之中。在這因果相續的過程中不 可能找出第一因, 這是因為它形成了一個圓圈, 即“生命之輪”。佛 教把生命看成圓圈。如此來反思生命, 它就是不斷地重複、無盡地 延續 ${ }^{4}$ 。

“輪迴”是因緣存在的總體, 它被比作一片汪洋, 其上的波浪代 表每次的生命, 每次的生命都影響下一次。有四種業招致來生, 它 們是現世受業、來生受業、後生受業和其結果完全失去其潛力的既 有業。只存在具備必要原因的因緣法, 任何個體都無逃乎其直。5

佛教認為, 神識是永㥀不滅的, 當人們活著的時候, 它與肉體 結合在一起, 經歷人間的悲歡離合, 而當人們死後, 它又會逐漸脱 離日漸潰朽的肉體, 經歷中陰世界的各種考驗。人在世間時, 無論 是清醒時, 還是沉睡時, 人們的意識波動就從來沒有停止, 同樣死 亡後進入中陰世界, 意識不但不會消滅, 反而會成為中陰世界的主 角。 ${ }^{6}$

世間萬物都是由地、火、水、風這四大元素所合成, 而人類的 肉身也是如此。當人瀕死之際, 我們肉身中的四大元素會逐漸分解 及衰退, 清楚地顯現各種死亡徵兆。四大分解是死亡過程中肉體最 痛苦的時刻, 在這個過程中, 身體的功能相繼失效, 視、聽、嗅、味、 觸等各種感覺逐一離我們而去。7

以無心跳的屍體供者的器官作移植時, 供者被切取器官時心 跳、迴圈已停止，但心跳停止的時間不能過長，因移植類別不同而

(4) 同上。

(5) 哈瑪拉瓦・薩達提沙著, 姚治華、王曉紅譯 : 《佛教倫理學》( 上海 : 上海譯文 出版社, 2004 年), 真 18-19。

(6) 蓮花生大師原著, 達赫釋著: 《西藏生死書》( 西安: 陝西師範大學出版社, 2006 年), 頁 34-35。

(7) 同上, 頁 52 . 55 。 
異。如腎臟一般不超過 30 分鐘, 而肝臟在 5-8 分鐘內, 心跳停止後 在準備手術前, 往往需要人工心臟按摩以減少缺血損害。這與佛教 的理論是背離的。

在佛教界, 淨土宗特別反對器官移植; 當前流行的理論是：臨 終與死後 8 小時內, 亡者神識尚存, 故尚有知覺作用, 死後妄動身 體, 將給亡者帶來極大的痛苦。因此, 初死 8 小時內不宜移動屍體, 以免令亡者因痛生嗔, 失去正念, 而構成往生西方淨土的障礙。甚 至墮入惡趣, 生起無量罪業。8

人死之後, 如果馬上移植器官, 如摘除眼角膜、皮膚或其他藏 器, 死者必然也會感受到非常強烈的痛苦; 若因此而生起嗔惱, 障 礙其往生善趣或是往生淨土, 則生前功德都將付之一炬。9

死亡是人一生中最後一件大事, 它對於一個人來説, 決不僅 僅意味著這一世的結束。死亡是一個機遇, 也是一場選擇, 是一場 輪迴與解脱的選擇, 因為神識是不滅的。當一個人咽下最後一口氣 時, 他的神識並沒有離我們而去, 其神識正經受著如生龜脱殼一般 的痛苦，如果我們漠然忽視亡者心靈上的痛苦，就會使亡者枉受極 大的悲慘。活著的人難道不應該幫助亡者, 使他們的神識免受隨善 惡業而生沉流轉之苦, 引導他們的神識出離三界而獲得解脱的自在 之樂, 為他們的心靈創造一個安寧、清淨的環境嗎?

\section{2. 佛教的生死分際的判定標準——阿陀那識執受根身反對腦 死亡概念}

2004 年, 衞生部在《中華醫學雜誌》上刊出了相關的腦死亡判斷 標準討論稿。有學者認為, “腦死亡是一種與呼吸機有關的特殊臨床 死亡狀態”，“腦死亡是以中樞性自主呼吸完全停止為首要特徵的腦

（8）釋昭慧：《佛教規範倫理學》( 台北：法界出版社, 2003 年), 頁 195 。

(9) 同上, 頁 196 。 
幹或全腦功能永久性喪失, 並且正在使用呼吸機人工通氣維持無效 心跳的一種特殊臨床死亡狀態。”腦死亡概念的推廣，更大的意義在 於推動急救醫學的進步, 現代臨床急救醫學的目的是在知情同意的 前提下等待捐獻器官。推動腦死亡臨床實踐, 不會增加自願捐獻者 的絕對數, 但是可以減少捐獻的失敗率。現代急救醫學已建立的兩 大原則是：盡一切努力“搶救生命”; 當搶救生命不成功時, 盡一切 努力“搶救器官”。現代深切治療策略的偉大進步之一在於正確把握 尊重生命和尊重死亡的時間轉換點, 並且賦予死亡新的生命價值, 讓生命在終點後延續！ ${ }^{10}$

但是從佛教生死分際的判定——阿陀那識執受根身的觀點出 發，這種移植術也是不可行的。佛法的十二緣起支中，有“識”與“名 色”二支，“識緣名色，名色緣識”，彼此是相依的關係。此中，眼、 耳、鼻、舌、身、意等六識都是“名”——精神的作用，眼、耳、鼻、 舌、身等五根就屬“色”——物質的作用。名、色之外，又有一“識”， 可見得這個“識”是與“名”不同的精神層次，應屬於更核心的生命中 樞。如果從根本典籍《阿含經》來看, “無明覆, 愛結系, 得此識身。” 這“識”應是前六識 ( “名”) 以外的“有取識”，這在大眾部名之為“根 本識”，在唯識學名之為“阿賴耶識”，或“阿陀那識”。唯識學將它的 功能做了很透徹的介紹：

何緣此識亦複説名阿陀那識? 執受一切有色根故; 一切 自體取所依故。所以者何? 有色諸根由此執受無有失 壞, 盡壽隨轉。又于相續正結生時, 取彼生故, 執受自 體。

(10) 陳忠華: 〈以呼吸機為中心, 重新定義腦死亡), 《醫學與哲學》(大連: 大連醫科 大學醫學與哲學編輯部, 2008 年 29 卷 1 期 ), 頁 16 。 
原來，它是生命中樞，眾生死後，它會執取構成生命的原質， 以結生另一期的生命; 如果下一期生命的形態是欲界胎生, 它就會 執取父精母卵，結合而成受精卵，這就是唯識學所謂“結生相續”的 功能。其次, 從入胎以後, 胚胎逐步成形, 然後出生、成長, 一直 到死亡，這期間，它都會牢固地執受根身，與根身“同共安危”，唯 識學者認定：此即《阿含經》所指“識不離身”的明證。11

唯識學派依“識不離身”之教, 將前六識一一加以核驗, 結論是: 此“識”決非前六識，因為前六識均有生滅——前五識有時生起，有 時不起; 第六識在正常時候雖不間斷, 但是“除生無想天，及二無心 位, 睡眠與悶絕。”這些時候, 意識是完全中止的。然而在意識中止 時, 為什麼人還活著呢? 為什麼身體的各種機能並沒有停頓, 新陳 代謝正常運轉呢? 由此可見, 有一個更深細的生命作用存在, 它在 執取著身體, 所以身體不須要心念指揮, 就能夠自動職司新陳代謝 的種種功能。這些, 都是六識功能之外的生命作用, 職司此一生命 中樞功能者，在根本佛法中，應即是六根中的“意根”、十二緣起支 中的“識支”，就唯識學的詮釋，是為“阿陀那識”執受根身的作用。12

傳統對死亡的定義是：呼吸停頓, 心臟停息。依佛法看，呼吸 停頓，不一定就是死亡，印順導師在論“死”時提醒此點：“通俗以呼 吸停止, 沒有知覺為死亡。然如溺水、縊死等呼吸停止, 每能依人 工呼吸而恢復, 所以但憑呼吸停止, 是不能確定為死亡的。(佛教及 外道) 修得第四禪的，“身行滅”——出入息停止了，然身體健康， 等到一出定, 呼吸就立刻恢復了。”

但是心藏停止，就真可以説是死亡了。原來依“執受”原理，我 們可以進一步推論：心藏停息，是因為阿陀那識已經停止了“執受根 身”的作用。阿陀那識起作用時，是跟身體的溫度和壽命的持續有關 係的。如果死亡以後, 身識還會起作用以覺受痛餈, 意識還會生起

(11) 釋昭慧: 《佛教規範倫理學》( 台北: 法界出版社, 2003 年), 頁 198-199。

(12) 同上, 頁 200 。 
貪嗔癡等煩惱, 那就表示阿陀那識並沒有離開根身; 倘若阿陀那識 依然執受根身, 則身體各個器官的運作, 就不會停止, 心臟依然跳 動, 血液就會迴圈, 體溫就不會冰冷……這生與死之間的界限, 就 在於阿陀那識執受或放捨身體。執受時, 壽暖與俱; 放舍時, 壽暖 俱斷。

我們可以進一步分析痛苦、嗔惱等覺受情緒的功能與阿陀那識 的關係。身體會感覺到痛苦, 那是身識的功能, 而身識與眼、耳、 鼻、舌識, 都是有間斷的; 意識會生起嗔等煩惱, 但它一樣會間斷。 前六識, 包括身、意二識, 都是隨著生命中樞的阿陀那識而轉起的, 算是生命中第二位階的身心功能, 阿陀那識執受根身時, 它們會随 緣俱轉, 如果阿陀那識已經放舍根身, 則次一位階的身、意二識, 援例應不可能再為轉起。這是位階層次的問題, 兩者間的關係可以 如此類推 : 有阿陀那識者, 不必然會轉起前六識; 可是, 有前六識 的生起, 就證明其背後一定有根本識而為依持。所以, 如果説, 一 個人業已死亡, 阿陀那識已不再執受根身, 而摘除器官時, 亡者竟 然還會感覺痛苦, 還會生起嗔惱, 這是匪夷所思的。再者, 心藏停 止之後, 縱使尚未馬上周身冷透, 阿陀那識隨冷觸起而逐漸離身的 過程中, 只要患者已呈現深度昏迷的狀態, 則阿陀那識有微細難了 的舍受, 六識又在停頓狀態, 身識的痛感與意識的情緒是不會生起 的。 ${ }^{13}$

“死亡”的確切定義, 因器官移植的需要而產生了爭議。傳統 上, 死亡的認定來自心藏停止, 如前所述, 佛法的“識執受”論是可 以接受傳統的死亡定義一心臟停止。由於器官移植是力求時效, 因而提出腦死亡的概念。然而腦死到底究竟是不是死亡? 這在歐 美、日本都產生過劇烈的爭議。這種由於器官移植術而產生的“腦 死”名詞, 不但提供了生與死的新界限, 而且還被人拿來巧妙利用,

(13) 釋昭慧: 《佛教規範倫理學》( 台北: 法界出版社, 2003 年), 頁 203 。 
嚴重模糊了生與死的界限。 ${ }^{14}$

印順導師在《華雨集》中有一段就死亡的問題而做“腦死即六識 不起”的確認。他認為：

腦死就是腦幹停止作用了, 此時不會再有痛覺。當然, 慢説是腦死, 就是腦昏迷指數在二或三時, 是否還有痛 覺? 答案也可能是否定的。動手術麻醉過去, 同樣也不 會有痛覺; 不但如此, 連修習禪定成功後, 到了前三禪 的階段, 也只剩下心的喜受和身的樂受, 而沒有任何苦 受憂受。所以腦昏迷指數近於零的患者, 是有可能因神 經傳輸功能中斷而不再傳達痛楚。

但這並不表示, 任何人有權在他心藏還跳動, 體溫還未冷卻, “識不離身”的時候, 宣判他的死亡。如此, 腦死的定義會不會使催 勸供體或摘除器官的醫護人員犯下“殺生”的業行? 醫生的角色本來 是要救人, 但是為了爭取時效以醫治需體, 稍一不慎, 就會變成供 體的催死者。就供體一方而言, 固然身布施是一種美德, 但是作為 需體的受贈者或醫護人員的第三者, 全力維護供體“生”的權利, 直 到識已離身, 壽暖已盡, 豈不才應該是最大的考量! 需體的生命權 固然值得重視, 供體的生命權豈不更應重視? 畢竟器官的原始擁有 人只要還有生命跡象, 就理應優先保存器官, 而不宜以任何理由巧 取豪奪 ${ }^{15}$ 。

傳統標準下死亡的患者, 其某些器官常會出現缺血性壞死而無 法移植, 或因為等待時間較長而大大降低移植的成功率。死亡捐獻 原則在一定程度上限制了移植器官的獲得和使用效率。因此, 以心

(14) 同上, 頁 200 。

(15) 同上, 頁 212-213。 
肺功能喪失作為死亡的判定標準, 呼吸迴圈停止導致體內器官缺血 性壞死, 從而大大降低了移植手術的成功率。而實行腦死亡標準, 醫生可以通過現代醫療技術, 使腦死亡病人的心、肺及其他器官 免於衰竭, 這些腦死亡病人的器官便成為移植手術的理想供體。為 了保護接受移植者的生命和健康權利, 而對死亡重新定義, 否定腦 死患者的生命價值, 這就意味著前者的生命較後者具有更大的優先 權。這一點是違背生命倫理的基本原則 ${ }^{16}$ 。

以腦死亡供者的器官作移植時, 因供者的迴圈、心跳、呼吸仍 可用人工輔助方式維持, 切取移植物時在接近正常呼吸迴圈功能的 情況下進行, 且熱及缺血時間短, 移植易於成功 ${ }^{17}$ 。如果不採取腦死 定義, 那麼器官移植以濟世活命的功效必然大減, 有些移植項目, 甚至會因此而完全無效。但為了讓社會重視“活死屍”的對等人權， 我們還是要提醒一點：宣判腦死以利於器官移植, 這其實是和執行 “安樂死”以結束患者痛苦一樣, 既可稱之為“功德”, 又可以名之為 “罪惡”, 功德與罪惡, 只在當人一念之間, 這是何等兩難的倫理處 境! ${ }^{18}$

佛教經典裏有布施波羅密“破除我執”，向別人供養腦、目、髓 的記載。器官移植與布施波羅密似乎有很大的關係, 佛教是主張“無 我” 的。那麼佛教徒是如何看待器官移植的呢? 首先他們願不願意 接受別人的捐贈? 一個真正的佛教徒是不會接受的。其次他們是否 應該捐贈器官? 佛教認為人有三世, 因此對身體的執著應該減輕, 高僧認為要不要捐贈器官得你自己衡量是否達到了“破除我執”的境 界。19

(16) 胡林英 :〈對我國腦死亡立法問題的反思〉, 載《醫學與哲學》(大連 : 大連醫科 大學醫學與哲學編輯部, 2008 年 29 卷 1 期 ) , 頁 20 。

(17) 孫福川: 《醫學倫理學》( 北京: 人民衞生出版社, 2007 年), 頁 160 。

(18) 釋昭慧: 《佛教規範倫理學》( 台北: 法界出版社, 2003 年), 頁 213 。

(19) 蔣勁松: 〈佛教與生命倫理學〉, 取自 http://www.tecn.cn/data/detail, 2001 年 6 月 1 日。 
淨土宗屬於大乘, 自然認同“學佛者要捨已為人”的偉大思想， 對於菩薩發願為眾生舍頭目髓腦的慈悲心行, 並無疑義。但是他們 認為：在還沒有達到第八地的無生法忍以前, 不要輕易這樣做, 以 免因痛惱所纏, 嗔心所感而墮入惡趣。所以面對“不肯捐贈器官以延 人壽命, 有違大乘精神” 的質疑, 他們的答復是：修行要有次第, 作 為凡夫的淨土行人, 先以順利往生為第一要務, 只要往生淨土, 自 可在佛菩薩大善知識的教導之下, 得不退轉, 證無生忍, 屆時有了 大堪忍力, 再回娑婆, 為眾生舍諸身肉, 都還不遲。20

佛教強調對於危重病人不必不顧一切地延續他的生命, 沒有必 要特別執著地挽救一個時期的生命。因此佛教提倡自然死亡。所謂 自然死亡就是提供一般的醫療手段讓病人按照病情發展的規律自然 死去。佛教認為人的生命長短並不重要, 重要的是死的狀態, 必須 説服病人讓他們明白輪迴是必然的, 死亡之後可以進入極樂世界, 因此死亡是不可怕的。21

佛教的世界觀和人生觀是三世因果六道輪迴，佛教所列六道， 天、阿修羅、惡鬼、地獄皆是化生, 人和畜生亦有化生, 乃至西方 極樂世界有情亦是化生。化生如夢, 各不相知。隨各人行為的影響 (業感)而各受其報。業同者生於同一環境。地球上數十億人，地球 乃數十億人共業所感, 亦是無數動物共業所。22

\section{二、佛教的護生觀和平等觀反對異種移植}

按照器官移植是否來源於人類, 可以分為同種器官移植和異種
(20) 同 (18), 頁 196 。
(21) 同 (19)。
（22）釋隆蓮: 〈佛教的道德觀〉, 載《清涼橋》( 湖北: 清涼山佛學苑, 2004 年 1 期 ), 頁 7 。


器官移植。以某一物種的細胞、組織、器官作為移植物, 移植到另 一物種體內, 稱為異種移植。在醫學界, 期望將動物如狒狒、猪的 細胞、組織或器官移植於人體, 達到治療疾病的目的, 是研究異種 移植的動機與願望。

1984 年 10 月 14 日，一名患有左心發育不全綜合症的女嬰誕生 在美國南加利福尼亞州的一家社區醫院。患有此綜合症的嬰兒, 心 臟的左側比右側小得多, 輸送的血液不足, 只能維持幾周的生命。 這種病的發生率約為一萬二千分之一, 佔全部新生兒的心臟病死亡 數的四分一。10月 26 日, 這個女嬰被送往 Lona Linda大學醫學中心， 由 L. Baile 醫生領導的醫學小組摘除了嬰兒有缺陷的心藏, 代之以 為一個狒狒的心臟。2 2 天以後, 即 11 月 5 日這個世界聞名的第一 個接受狒狒心藏的嬰兒死了 ${ }^{23}$ 。

為了人類的利益, 這種魯莽的醫療技術正在逐步開展, 人類的 迫切需要掩蓋了殘酷的事實: 狒狒已瀕臨滅絕, 全世界僅剩 10 萬隻, 其中就有 2500 隻被囚禁在美國。在醫療領域及其他科學領域對狒狒 的需求量也是非常大的。把狒狒用於研究特別是醫療領域研究中所 取得的科學成績引來了很多理論方面的爭論。世界上一切有生命的 存在體都是有價值的、值得尊重的。一切以人類的利益為中心的立 場是錯誤的，對其他動物輕視則是不公平的 ${ }^{24}$ 。

由於器官移植供體嚴重短缺, 科學家考慮從跨物種移植中尋找 出路, 卻引發了更為激烈的倫理爭論。1. 動物的權利：以湯姆·雷 根 (Tom Regan) 為代表的動物權利主義者認為, 動物享有和人一樣的 權利, 反對任何形式的在人和動物間權衡利益的選擇, 因此也沒有

(23) 雷瑞鵬、殷正坤: 《關於異種移植研究的爭論》, 載《醫學與哲學》(大連: 大連 醫科大學醫學與哲學編輯部, 2003 年 24 卷 10 期) , 頁 3 。

(24) 同上。 
必要討論“爔牲”一個狒狒去挽救一個患者是否有道義上的合理性。 他們認為, 異種移植是人類在“物種主義”或“人類中心論”觀念驅使 下的不理智行為。2. 自然法則問題：崇尚自然的人認為, 不同物種 間生物物質的相互混雜在基本道義上違反了自然法則，降低了人的 價值與尊嚴。且不説“混合人”的出現是否會帶來諸如“狼心狗肺”之 類的社會指責, 接受動物器官的人在婚姻、就業、保險等方面受到 歧視是可以預見的。3. 跨物種感染可能是更為嚴重的問題：異種移 植的安全性和有效性到目前為止是不確定的, 其中的安全性不僅是 對接受移植的病人是否安全, 而且是對整個人類是否安全。異種移 植提供了一個傳染疾病尤其是病毒疾病的可能途徑。某些動物內源 性逆轉錄病毒一旦轉到人體可能帶來致死性打擊, 如果整合到人基 因組中還可能給人類進化帶來禍害。異種移植技術確實能緩解人類 供體器官嚴重不足的問題, 解除許多晚期病人的痛苦及提供現實的 希望。可另一方面, 雖然目前還沒有十分確定的異種移植中跨物種 感染存在或不存在的證據, 但我們不可忘卻歷史的教訓：曾在歐洲 中世紀毀滅數千萬人的“黑死病” ( 鼠疫) 是從挈齒動物傳染到人的。 目前有證據表明, 愛滋病很可能是從靈長類傳染到人的。克雅病 (Creutzfeldt-Jacob Disease) 與瘋牛病的可能聯繫已經有很多討論 ${ }^{25}$ 。

如果以佛教的護生觀和平等觀來看待異種移植, 這種技術同樣 不可行。

佛教教義中有兩大要點：第一是緣起論, 第二是護生觀。緣起 論是精密的因果律, 佛法以此為總綱, 解明世間生成與還滅的原理。 護生觀則是佛法中一切倫理規範的終極精神 ${ }^{26}$ 。

(25) 張新慶 : 《歷練你的生命智慧——解讀生命中的倫理難題》( 北京：科學普及出 版社, 2007 年), 頁 17-18。

(26) 釋昭慧: 《佛教倫理學》( 台北 : 法界出版社, 2004 年), 頁 64-65。 
從自通之法、緣起相的相關性和緣起性的平等性三方面來證明 護生不只是美德, 而是一種倫理責任, 不但佛弟子必須努力, 一般 人也不例外。1. 從原始的《阿含經》到大乘經典, 處處説明護生的理 由一一自通之法。《法句經·刀杖品》説：

一切懼刀杖, 一切皆畏死, 以自度(他情), 莫殺教他殺。 一切懼刀杖, 一切皆愛生, 以自度 (他情), 莫殺教他殺。 于求樂有情, 刀杖加惱害, 但求自己樂, 後世樂難得。 于求樂有請, 不加刀杖害, 欲求自己樂, 後世樂可得。

從最庸俗的自利觀點出發, 也要意識到因果報應的問題: 如是 因如是果, 自己愛生畏死, 就要在消極方面避免傷殺眾生, 以免招 感與被害者同樣的果報時, 自己痛苦不堪; 另外還要積極愛護眾生, 以感得與受施者同樣的樂果——這就是“于求樂有情, 不加刀杖害, 欲求自己樂, 後世樂可得。”的原理。但這還是典型的“自利”式護生 行為, 若進一步存念利他, 這才是“自通之法”的崇高精神: 用自己 的心情, 揣度其他眾生的心情, 而珍重他趨生畏死、趨樂避苦的天 性。每一眾生都會愛惜自己的生命; 當外事外物有益於他的生命時, 他會歡喜、感激; 若戕害他的生命或造成生命的災難時, 他會悲哀、 憤怒、恐懼, 甚至會報復。所以, 站在體貼眾生的立場, 我們不要 隨意地去惱害其他的生命, 並體貼他受傷時的痛苦, 這是“以自度他 情”的同理心, 就是護生的第一步。2. 緣起相的相關性 : 這可從時空 兩方面來看。同為空間內的一切法一一物質、心識、生命, 看似個 別獨立, 而其實都是相依相成的緣起法。既然必須依託因緣, 才能 產生現實的存在, 這就使得人與世界、人與人、人與動植物、乃至 人與無生物之間, 結成一個綿密的網路。這種“關係的存在”, 使得 人雖然看似為個體的獨立活動, 其實卻受著關係的決定。既然人與 
人之間, 與眾生之間都如此密切相關, 自然會生起或多或少的同情。 同情，依於“覺得彼此間有一種關係”的共同意識, 由此而產生親愛 或關切之情, 甚至擴充而為與樂或拔苦的慈悲心行。從時間的三世 (過去世、現在世、未來世) 來説, 一切眾生因我見不捨, 所以愛著 身心聚合的生命; 死已復生, 生生不已。在這永無休歇的生命旅程 中, 每個人與一切眾生, 從無始以來, 都有著非常密切的關係, 過 著共同而密切的生活, 現在雖然未必相親相識, 但過去未來的無數 生中，他們都很有可能曾為“我的父母，我的兄弟姊妹，我的夫婦兒 女。”由以上可見, 一切眾生對我都有恩德。所以, 從菩薩的心境看 來, 一切眾生都如我父母, 如兄如弟, 如姊如妹, 理應與他們和樂 相向。護生為道德的根源, 為道德的最高準繩, 這是人心映現緣起 法則而流露的一一對自體以外其他眾生的關切同情。3. 緣起性的平 等性：大乘法説：眾生平等; 不但如此, 連眾生與佛也都平等, 因 為“有因有緣世間集”而產生眾生, “有因有緣世間滅”而產生諸佛, 一切眾生都有成佛的可能性—— “佛性”。這些都是從法性平等的現 觀中得來的。一切眾生, 特別是人類, 不但由於緣起相的相依相存 而引發共同意識, 而且每每是無意識地, 直覺得對於眾生或人類的 苦樂有共同感。27

佛教道德在以普度眾生為宗旨和以善為基礎的前提下，有幾條 主線始終貫穿於整個道德體系的全部內涵之中, 並起著綱領和支撐 的作用, 這就是平等、忍辱、誠實、精進。呈徵在《清靜毗尼方廣經 講要》中指出, “平等者為一切佛法之根本, 一切學行簡言之, 致平 等而已矣。”佛教認為, 從法性上講, 眾生都是由四大、五蘊和合而 成, 都具有無常的特性, 而沒有任何例外, 這是平等的基礎。釋迦 牟尼曾經講, “過去與未來, 及以今現在, 無有諸眾生, 不歸無常者。

(27) 釋昭慧:《佛教倫理學》( 台北: 法界出版社, 2004 年), 頁 75-76、78、81-82。 
如來天人尊, 金剛身堅固, 猶不免無常, 而況餘人。”而從佛性上講, 眾生人人皆具佛性, 《壇經》上講: “假如能夠清楚地認識眾生, 就是 佛性, 假如不能清楚地認識眾生, 那就萬劫䚇佛也難遇。我現在教 你們認識自己心中的眾生, 並見自己心中的佛性。要想見佛, 只在 能夠認識眾生; 因為只是眾生迷了自性佛, 不是佛迷眾生。自己的 心性如果了悟, 眾生亦就是佛; 自己心性如果迷失, 佛亦就是眾生。 自性若是平等, 眾生就是佛; 自性若是邪險, 佛就是眾生。你們的 心裏如果險曲不正, 就等於佛在眾生中; 如果一念平等正直, 就等 於眾生成了佛。我們自己心中本來就有佛, 這自性佛才是真佛。自 己倘若沒有佛心, 更到何處去䍃真佛呢? ”佛教的平等, 除法性和 佛性以外，還反映出普遍意義上的因果平等，這就使佛教的平等觀 具有更加徹底的意義。佛經上講, “眾生與佛心法性同, 由生性而説 因同, 及至佛所證心法而説果同。又由因同故謂眾生皆有佛性, 由 果同故謂涅般木一味等味。”所以, “因果平等無有差別”。這樣, “佛 教以依怙心為信仰、修行目的, 再與所依怙佛達到平等地位, 解脱 成佛。佛與弟子為師徒關係、先覺與後覺關係……理論上, 佛教認 為能依怙的眾生與所依怙的佛, 體性平等、唯是一心、自他不二、 生佛不二、心佛不二。”特別是在眾生的解脱上，佛教認為所有人都 是平等的, 都可以得到解脱。不但各種種姓 (婆羅門、帝利、吠舍、 首陀羅)、各階層 (國王、大臣、貴族、平民、甚至妓女等)，以至於 天師外道、惡人等, 都可以通過對佛教的信仰、修行而獲解脱。同 時, 佛與佛之間也是平等的關係, 一佛即諸佛, 諸佛即一佛, 佛佛 相照無有主次。佛教還從各個具體的不同角度要求眾生, “積集一切 功德平等心, 發一切差別願平等心, 于一切眾生身平等心, 于一切 眾生業報平等心, 於一切法平等心, 於一切淨穢國土平等心, 于一 切眾生解脱平等心, 於一切行無所分別平等心, 於一切佛力無畏平 等心, 於一切如來智能平等心。” 
從以上可以看出, 佛教的平等是真正意義上的平等。由於佛教 平等觀的統攝作用，因此，眾生在世間的日常活動中，也就不應有 高下、大小、貴賤、貧富、榮辱之分，正如佛經上所講，“觀諸眾生， 如一子想。”“六道眾生, 皆我父母。”都應親如一家, 平等相待, 和 睦相處、相敬如賓、同修法門、共獲涅般木。28

廣義而言, 每一項器官移植技術的發展, 都隱藏著許多實驗動 物的苦難和血淚。因為, 沒有經過一次又一次的嘗試失敗, 器官移 植術是不可能輕易做人體醫療用途的。而嘗試失敗的物件當然是那 些被人類沙文主義者認為“次等生命”的各種實驗動物了。 29

怨怨相報, 無始無終, 六道輪迥也就沒有窮畫。動物是 畜牲道的眾生。我曾經聽過或在報刊上看過很多動物救 人的故事。動物把人當作朋友、主人, 對人無比忠誠, 大仁大義, 當人類有危難時, 牠挺身而出, 捨已為人。 那種勇於犧牲的精神, 實在叫人感動不已, 催人淚下。 相比之下, 人類卻在残害動物, 殺害動物。作為人類的 一員, 我為人類的行為, 感到無比的慚愧。3 30

我們是否真的需要異種移植? 異種移植會否改變我們對人的定 義? 我們會否更改自然選擇規律? 生命是否值得不惜一切代價去延 長? 對於受體來説, 他將受到心理和生理上的怎樣影響? 社會對此 的看法如何，以及將來他的後代會是怎樣? 同時, 對於動物的影響， 我們是否應該關注動物的權利? 這些問題都值得人類去認真思考的。

(28)〈論佛教道德體系及其主要內涵〉, 取自 http://www.wuys.com , 2007 年 12 月 17 日。

（29）釋昭慧：《佛教規範倫理學》( 台北：法界出版社，2003 年)，頁 220 。

(30) 悲 勤: 〈我為人類行為感到無比慚愧〉, 載《清涼橋》( 湖北: 清涼山佛學苑, 2004 年 3 期 ), 頁 54 。 


\section{三、從佛教觀點看器官商業化更不可取}

增加器官供應的另一個可能是允許器官在公開市場出售。2000 年夏, 英國人喬治到土耳其旅遊, 並在該國一家大醫院進行了腎臟 移植手術, 但因失敗後死亡。他的妻子後來透露, 供體腎取自一位 土耳其人, 因捐獻自己的腎臟而獲得三千英鎊的報酬。當問及這位 土耳其人為什麼要出賣腎時, 他説他需要支付他女兒的醫藥費 ${ }^{31}$ 。

對於西歐那些患有腎衰竭的富人來説, 只要肯出錢, 只要到歐 洲之外的貧窮國家進行一次旅遊, 就可以找到中意的器官。這種“器 官移植遊”近年來生意興隆。歐洲人的“器官移植遊” 最早始於 20 世 紀 80 年代。當時, 一些有錢的病人前往印度、巴基斯坦以及東南亞 等國, 他們借旅遊的名義從當地貧窮的器官捐獻者那裏接受器官移 植 ${ }^{32}$ 。

器官買賣可能緩解了一部分器官私有短缺的情況, 但同時它 也可能帶來許多弊端。首先, 器官買賣損害了人類的價值觀, 將人 體變為商品是對人類尊嚴的衮瀆; 其次, 器官買賣的第一目的是利 潤而不是患者的利益, 供體為了出售器官很可能會隱瞞他的真實病 沉、遺傳病史、家族病史等, 不能保證器官的品質。在實踐中也會 產生諸多問題, 由於賣器官可獲巨利, 必然而且事實上已經引發穪 取器官的犯罪行為和犯罪團夥。正因為如此, 許多國家政府都制定 專門法律，禁止器官買賣。1995 年 4 月在西班牙馬德里召開的第 93 屆各國議會聯盟, 重申反對器官買賣的立場, 有 60 多個國家立法禁 止買賣人體器官 ${ }^{33}$ 。

(31) 張新慶 : 《歷練你的生命智慧——解讀生命中的倫理難題》( 北京 : 科學普及出 版社, 2007 年), 頁 17-18。

(32) 同上。

(33) 同上。 
更為重要的是, 它會加劇人們在生死面前出現的不平等, 有錢 人可以購買器官而獲得再生機會, 而貧窮的人只能在迫不得已的情 況下出售自己或家人的器官。富人在擁有更多醫療資源的優勢下, 去掠奪窮人的器官; 全世界每年有成千上萬的器官交易, 窮人變成 了富人的零件工廠, 這裏面隱藏了太多的陷阱與罪惡。美國醫學協 會 2002 年進行的一次調查發現, 在印度切奈地區的 305 位腎出售者, 平均每出售一個腎只得到 1070 美元。調查發現，96\% 的腎出售者是 由於家庭經濟極端貧困迫不得已而接受腎摘除手術，但出售腎臟的 窮人只能暫時解決經濟困境, 腎摘除手術後, 平均每個家庭的收入 下降了三分之一。四分之三的腎出售者稱, 他們仍債務纏身。幾乎 所有的人都報告説, 他們自腎摘除後健康狀況急劇下降。34

只因供體是生命卑微的窮人或命若遊絲的“活死屍”，這就是 “強凌弱”的生態，這是不符合佛教的“眾生平等”的精神。無論如何， 器官來源的困難, 使得器官移植從捨已助人的義行, 淪為可以論斤 稱両的商機, 這實在是倫理上的極大諷刺 ${ }^{35}$ 。

器官移植技術的發展如今已變成殺生利器; 它固然造福了無數 患者, 但也挾持著金錢、權力與人類沙文主義的意識形態, 兇狠地 撲向弱勢的窮人、嬰兒、胚胎與數不清的動物。

站在佛法的立場上反省人類的這項發明, 我們冊寧要明確地 説：現代的器官移植科技, 經常在“仁心濟命”的表象底裏, 合理化 了“殘忍奪命”的行動，有違佛法“不殺生”的根本戒律，而且活用動 物、胎兒乃至嬰兒組織以及器官商品化都隱藏著“強勢欺凌弱勢、富 人掠奪窮人”的階級罪惡，有違佛法“眾生平等”的精神 ${ }^{36}$ 。

(34) 張新慶 : 《歷練你的生命智慧——解讀生命中的倫理難題》( 北京 : 科學普及出 版社, 2007 年), 頁 17-18。

(35) 釋昭慧: 《佛教規範倫理學》( 台北: 法界出版社, 2003 年), 頁 220 。

(36) 同上, 頁 196 。 


\section{參考文獻}

哈瑪拉瓦・薩達提沙著, 姚治華、王曉紅譯 : 《佛教倫理學》, 上海 : 上海

譯文出版社, 2004 年。

孫福川:《醫學倫理學》, 北京: 人民衞生出版社, 2007 年。

張新慶: 《歷練你的生命智慧——解讀生命中的倫理難題》, 北京: 科學普及 出版社, 2007 年。

蓮花生大師原著, 達赫釋著: 《西藏生死書》, 西安: 陝西師範大學出版社,

2006 年。

釋昭慧：《佛教倫理學》, 台北：法界出版社, 2004 年。

釋昭慧: 《佛教規範倫理學》, 台北：法界出版社, 2003 年。

胡林英: 〈對我國腦死亡立法問題的反思〉, 《醫學與哲學》, 大連: 大連 醫科大學醫學與哲學編輯部, 2008 年 29 卷 1 期。

陳忠華: 〈以呼吸機為中心, 重新定義腦死亡〉, 《醫學與哲學》, 大連: 大連醫科大學醫學與哲學編輯部, 2008 年 29 卷 1 期。

悲 勤: 〈我為人類行為感到無比慚愧〉, 《清涼橋》, 湖北: 清涼山佛學苑 2004 年 3 期。

雷瑞鵬、殷正坤: 〈關於異種移植研究的爭論〉, 《醫學與哲學》, 大連 :

大連醫科大學醫學與哲學編輯部, 2003 年 24 卷 10 期。

釋隆蓮: 〈佛教的道德觀〉, 《清涼橋》, 湖北: 清涼山佛學苑, 2004 年 1 期。 理 方: 〈佛教與現代社會——緣起論為中心〉, 《首屆世界佛教論壇論 文專輯》, 取自 http://www.wuys.com。

將勁松: 〈佛教與生命倫理學〉, 取自 http://www.tecn.cn/data/detail, 2001 年 6 月 1 日。

〈論佛教道德體系及其主要內涵〉, 取自 http://www.wuys.com, 2007 年

12 月 17 。 